\title{
Coloboma of the Eyelid
}

National Cancer Institute

\section{Source}

National Cancer Institute. Coloboma of the Eyelid. NCI Thesaurus. Code C98878.

A congenital abnormality in which a part of the upper or lower eyelid tissue is missing. 